\title{
PERENCANAAN RUTE PENGIRIMAN UNTUK MEMINIMALKAN BIAYA TRANSPORTASI
}

\author{
RIJANI EFZI \\ Poltek Negeri Banjarmasin \\ Jalan Brigjin Hasan Basri Banjarmasin \\ E-mail: Rijani@yahoo.com
}

\begin{abstract}
PT. Indomarco Adi Prima represent one of the company which active in the distribution of product, handling of inefficient distribution represent main problem in this industry which cause the expense of high transportation. Of the condition needed some method to overcome the problem. Generalized Assignment method represents one of the methods which studying process delivery of goods to consumer in supply chain management is the routing and scheduling vehicles of deliveries. Especial target of this method is to plan the amount of proposal product allocation so that is later expected by minimization can the expense of product distribution. Before we apply Generalized Assignment method, is beforehand done by plotting and forecasting of request data 3 months come. Forecasting of demand by using method matching with result plotting of data, and then selected [by] smallest MAPE. After that result of the forecasting processed by using Generalized Assignment method. From data processing obtained by result with Generalized Assignment method (Pakis) obtained by cost-saving of distribution equal to Rp2.038.531,00/period of delivery or by cost-saving equal to 31.70\%. While for (Klojen) obtained by cost-saving of distribution equal to Rp1.215.589,00/period of delivery or by cost-saving equal to 22.19\%. The result for the distance after using Generalized Assignment method obtained (Pakis)by distance-saving of distribution equal to $116 \mathrm{~km}$ or by distance-saving equal to $18.86 \%$. And result for the distance after using Generalized Assignment method obtained (Klojen) by distance-saving of distribution equal to $13 \mathrm{~km}$ or by distance-saving equal to $3.74 \%$.
\end{abstract}

Key words: routing and scheduling vehicle, delivery cost

\section{PENDAHULUAN}

Sebuah perusahaan dalam bidang distribusi, untuk mempercepat pendistribusian produk, maka PT tersebut sudah membuka cabang hampir di setiap kota di Indonesia. Salah satu masalah yang dihadapi khususnya cabang Malang adalah semakin tingginya biaya pengiriman. Hal ini terjadi karena tidak teraturnya pola permintaan yang harus dikirim dari kantor cabang menuju Stock Point yang terdapat hampir di setiap kecamatan di Malang.

Generalized Assignment merupakan salah satu metode yang membahas proses pengiriman barang ke konsumen dalam manajemen rantai persediaan dan keputusan yang paling terkait adalah rute dan penugasan kendaraan pada distributor. Kelebihan dari metode ini adalah memperhatikan kapasitas kendaraan dan total waktu pengiriman dalam proses pendistribusian barang, serta penugasan pelanggan pada sebuah rute atau mengalokasikan konsumen-konsumen ke sebuah rute/kendaraan dengan menggunakan Integer Linier Programing sehingga hasilnya lebih optimal.

Metode ini diharapkan dapat membantu mengatasi permasalahan di atas sehingga industri menengah ini dapat merencanakan waktu, rute, dengan lebih baik dan biaya minimal setiap produk yang akan dikirim, berapa jumlahnya, kendaraan apa yang dipakai, dan ke mana tujuannya.

\section{METODE}

Studi pendahuluan. Langkah awal yang dilakukan dalam penelitian adalah mengadakan surveikeperusahaan, yaitu untuk mengetahui kondisi perusahaan guna mendapatkan permasalahan yang ada.

Identifikasi masalah. Setelah survei langkah selanjutnya adalah identifikasi terhadap permasalahan yang ada. Dalam hal ini mengenai terdapat ketidakefektifan pada pendistribuasian produknya, yaitu tanpa mempertimbangkan rute dan penugasan kendaraan sehingga mengakibatkan 
total kendaraan yang dibutuhkan lebih banyak, total jarak yang ditempuh lebih panjang, dan total waktu perjalanan lebih lama, yang akhirnya menyebabkan biaya transportasi tinggi. Di samping itu, keterlambatan pengiriman menyebabkan kekurangan produk di pasar sehingga mengakibatkan penurunan penjualan.

Setelah memperoleh data yang relevan kemudian dilakukan pengolahan data penjualan dengan menentukan pola grafik penjualan. Pola grafik kita dapat meramalkan penjualan dengan beberapa metode yang dipakai. Selanjutnya dapat dilakukan pemilihan metode peramalan terbaik untuk perhitungan selanjutnya dengan kriteria MAPE $\leq 10 \%$. apabila MAPE yang telah dihitung belum minimal maka kembali ke pemilihan metode peramalan untuk dicari MAPE yang paling minimal. MAPE terkecil (paling minimal) menunjukkan tingkat kesalahan peramalannya kecil. Ballou, H.R., (2004), Baroto, T., (2002).

Perhitungan perencanaan rute dan penugasan kendaraan pada distributor dengan menggunakan metode Generalized Assignment, yaitu dengan: (a) Pengalokasian seed point untuk masing-masing rute. Seed adalah Pusat perjalanan dari berbagai distributor dalam sebuah rute, $\mathrm{L}_{\text {seed }}$, adalah kapasitas rata-rata untuk pengalokasian tiap seed point, hal ini dinyatakan dengan $\mathrm{L}_{\text {seed }}$ : Salim, A.H.A., (1998).

$$
\mathrm{L}_{\text {seed }}=\frac{\text { Total Permintaan }}{\text { Jumlah Alat Angkut }}
$$

Melaju searah jarum jam dari $\theta$ untuk mendapatkan Cone yang akan dialokasikan dalam seed, yaitu:

a) Menentukan posisi sudut $\left(\theta_{i}\right)$ dari masing-masing distributor

$\theta_{\mathrm{i}}=\operatorname{ATAN}(y i / x i)$

b) Menggeser searah jarum jam untuk menentukan urutan distributor dalam penggabungannya.

c) Menentukan koordinat "seed point" dengan rumus:

$X_{i}=d_{i} \times \cos \left(\alpha_{i}\right) \quad Y_{i}=d_{i} \times \sin \left(\alpha_{i}\right)$

Rumus Jarak:

$\mathrm{d}_{(\mathrm{A}, \mathrm{B})}=\sqrt{\left(\mathrm{X}_{\mathrm{A}}-\mathrm{X}_{\mathrm{B}}\right)^{2}+\left(\mathrm{Y}_{\mathrm{A}}-\mathrm{Y}_{\mathrm{B}}\right)^{2}}$
- Pembentukan Cone yang selanjutnya di mulai dari sudut hasil perluasan customer terakhir.

- Seed Point membatasi Cone 1 dengan Cone 2.

Di masing-masing "cone", "seed point" dialokasikan di tengah (kaitannya dengan sudut) dalam sebuah jarak yang sama pada pelanggan (dengan sebagian atau penuh beban yang di alokasikan pada "cone") yang terjauh dari DC (Distribution Center).

(b) Pengevaluasian jarak tambahan untuk masingmasing distributor

$\mathrm{D}_{\mathrm{k}}=\operatorname{Dist}(D C, i)+\operatorname{Dist}\left(i, S_{k}\right)-\operatorname{Dist}\left(D C, S_{k}\right)$

(c) Pengalokasian distributor ke sebuah rute/ kendaraan. Yaitu dengan menggunakan Integer Programing:

$\operatorname{Min}=\sum_{\mathrm{k}=1}^{\mathrm{K}} \sum_{\mathrm{i}=1}^{\mathrm{n}} \mathrm{D}_{\mathrm{ik}} \mathrm{Y}_{\mathrm{ik}}$

Subject to:

$\sum_{\mathrm{k}=1}^{\mathrm{K}} \mathrm{Y}_{\mathrm{ik}}=1, \ldots, \mathrm{n}$,

$\sum_{\mathrm{i}=1}^{\mathrm{n}} \mathrm{a}_{\mathrm{i}} \mathrm{Y}_{\mathrm{ik}} \leq \mathrm{b}_{\mathrm{k}}, \mathrm{k}=1, \ldots, \mathrm{k}$,

$Y i k=0$ atau 1 untuk seluruh $i$ dan $k$

(d) Pengurutan distributor pelanggan pada sebuah rute. Perencanaan urutan costumer dalam satu rute dengan metode/prosedur Nearest neighbour.

Perhitungan perencanaan rute dan penugasan kendaraan pengiriman produk awal. Perencanaan rute dan penugasan kendaraan pada distributor berdasarkan keadaan awal yang terdapat di perusahaan sebelum diadakan perhitungan oleh penyusun.

Menghitung perbandingan total biaya pengiriman, dengan biaya pengiriman usulan. Ada beberapa biaya yang berkaitan dengan pengiriman yaitu: Biaya operasional; biaya yang meliputi kebutuhan finansial kendaraan meliputi biaya bahan baker, biaya tak terduga dan biaya maintenance kendaraan (Herjanto, E., 1999).

Membandingkan biaya total waktu pengiriman untuk mengetahui penghematan yang diperoleh setelahmenggunakanmetodeGeneralizedAssignment (Hugos, M., 2004). Untuk menghitung penghematan biaya, adalah selisih antara biaya pengiriman sesudah perbaikan (setelah dilakukan analisis) dengan biaya pengiriman sebelum perbaikan. 


\section{HASIL DAN PEMBAHASAN}

Metode peramalan yang dievaluasi adalah beberapa metode yang sesuai dengan plot data permintaan masing-masing wilayah. Berdasarkan hasil plot data permintaan grafiknya berbentuk trend maka menggunakan metode trend linear dan single exponential smoothing. Sedangkan untuk plot data yang grafiknya berbentuk musiman maka menggunakan metode moving average dan winter method.

Dari masing-masing metode tersebut akan dipilih metode yang terbaik, yaitu berdasarkan nilai MAPE terkecil dan $\leq 10 \%$ sebagai ukuran dalam menentukan kesalahan. Untuk menghitung nilai MAPE, penyusun menggunakan Software Minitab. Kemudian yang memiliki nilai MAPE terkecil dan $\leq 10 \%$ adalah metode yang digunakan untuk meramalkan permintaan. Metode yang di pakai pada masing-masing Stock Point wilayah pengiriman berbeda-beda berdasarkan nilai MAPE (Makridakis, S., Wheelwright, S.C., Mc. Gee Victor E., 1998).

Analisis pengalokasian Seed Point untuk masing-masing rute. Berdasarkan hasil pengolahan data maka didapat koordinat seed point di masingmasing rute perjalanan. Besarnya beban seed point ini sama dengan besarnya $\mathrm{L}_{\text {seed }}$, sedangkan besarnya $\mathrm{L}_{\text {seed }}$ adalah adalah kapasitas rata-rata untuk pengalokasian tiap seed point, atau hasil pembagian antara jumlah total permintaan dengan jumlah alat angkut yang digunakan (Yamit, Z., 2003). Posisi seed point ini berada di tengah cone di masing-masing perjalanan, dari tabel ditunjukkan koordinat yang ada pada masing-masing seed point dari masing-masing Gudang ke wilayah pengiriman.

Tabel 1. Koordinat Seed Point dari Gudang Pakis (dalam km)

\begin{tabular}{cll}
\hline Seed Point & \multicolumn{1}{c}{$\mathbf{X}$} & \multicolumn{1}{|}{ Y } \\
\hline S1 & 7,8 & 12,9 \\
S2 & 12,39 & 16,8 \\
S3 & 35,2 & 42,35 \\
S4 & 20,1 & 22,2 \\
S5 & 31,05 & 32,4 \\
S6 & 33,37 & 33,37 \\
S7 & 6,79 & 1,54 \\
\hline
\end{tabular}

Tabel 2. Koordinat Seed Point dari Gudang Klojen (dalam km)

\begin{tabular}{ccl}
\hline Seed Point & $\mathbf{X}$ & $\mathbf{Y}$ \\
\hline S1 & 8,8 & 17,8 \\
S2 & 13,68 & 19,68 \\
S3 & 15,93 & 21,6 \\
S4 & 26,46 & 32,76 \\
S5 & 12,45 & 8,4 \\
\hline
\end{tabular}

Analisis evaluasijarak tambahan untuk masingmasing wilayah pengiriman. Jarak tambahan merupakan jarak yang di tempuh dari DC ke seed point dan kembali sehingga jarak tambahan ini diminimalkan. Berikut adalah hasil pengolahan jarak tambahan yang terjadi pada setiap seed point.

Tabel 3 dan 4 menunjukkan adanya perbedaan jarak tambahan di masing-masing seed point dan distributor, perbedaan ini karena jarak atau koordinat masing-masing distributor dan seed point berbeda-beda. jarak tambahan ini akan di pergunakan dalam perhitungan mengalokasian distributor pada sebuah rute kendaraan.

Analisis penugasan pelanggan pada sebuah rute atau mengalokasikan konsumen-konsumen ke sebuah rute kendaraan. Analisis penugasan dimaksudkan untuk mengalokasikan distributor pada sebuah rute perjalanan (Ballou, H.R., 2004). Pengalokasian ini menggunakan Integer Linier programming dengan menggunakan software QS (Quantitative System). Solusi yang di dapat dari penugasan distributor pada sebuah rute ini menghasilkan beberapa rute perjalanan yang dibagi sesuai kapasitas kebutuhan permintaan pada dua gudang, yakni Gudang Pakis dan Klojen. Penugasan distributor pada sebuah rute atau pengalokasian pada rute ini dengan mempertimbangkan batasan kapasitas alat angkut tersebut.

Berdasarkan pengolahan yang dilakukan, maka di dapatkan solusi pengalokasian wilayah pengiriman pada sebuah rute dari Gudang Pakis:

Rute 1: SP13, SP14, SP15, SP19, SP20

Rute 2: SP2, SP29

Rute 3: SP1, SP4, SP11, SP27, SP28

Rute 4: SP3, SP5, SP12, SP18, SP26

Dengan jarak tambahan sebesar 21,31 km, sedangkan solusi pengalokasian wilayah pengiriman pada sebuah rute dari Gudang Klojen adalah: 
Tabel 3. Jarak Tambahan (Gudang Pakis) pada Masing-masing Seed Point (dalam km)

\begin{tabular}{|c|c|c|c|c|c|c|c|}
\hline Tujuan & $\begin{array}{c}\text { Seed } \\
\text { Point } 1\end{array}$ & $\begin{array}{c}\text { Seed } \\
\text { Point } 2\end{array}$ & $\begin{array}{c}\text { Seed } \\
\text { Point } 3\end{array}$ & $\begin{array}{c}\text { Seed } \\
\text { Point } 4\end{array}$ & $\begin{array}{c}\text { Seed } \\
\text { Point } 5\end{array}$ & $\begin{array}{c}\text { Seed } \\
\text { Point } 6\end{array}$ & $\begin{array}{c}\text { Seed } \\
\text { Point } 7\end{array}$ \\
\hline Batu (SP1) & 30,45 & 19,11 & $-4,9$ & 2,35 & $-5,49$ & $-5,92$ & 45,68 \\
\hline Lowokwaru (SP2) & 8,11 & 2,35 & $-1,08$ & $-0,8$ & $-1,51$ & $-1,67$ & 19,13 \\
\hline Pujon (SP3) & 52,59 & 40,83 & $-8,72$ & 22,35 & $-5,69$ & $-9,32$ & 68,83 \\
\hline Karangploso (SP4) & 19,29 & 8,93 & $-3,25$ & $-1,69$ & $-3,79$ & $-4,04$ & 82,61 \\
\hline Dau (SP5) & 13,29 & 5,2 & $-1,31$ & $-0,56$ & $-1,82$ & $-2,05$ & 25,71 \\
\hline Lawang (SP11) & 29,87 & 18,18 & $-8,2$ & 0,01 & $-8,7$ & $-8,86$ & 46,18 \\
\hline Sukorejo (SP13) & 77,77 & 65,96 & $-0,25$ & 47,49 & 17,64 & 12,91 & 94,42 \\
\hline Tutur (SP14) & 138,01 & 126,2 & 58,16 & 107,78 & 77,89 & 73,22 & 154,76 \\
\hline Dampit (SP15) & 83,87 & 72,06 & 4,61 & 53,64 & 23,74 & 19,08 & 100,73 \\
\hline Wajak (SP18) & 41,22 & 29,48 & $-8,86$ & 11,05 & $-9,38$ & $-9,98$ & 57,49 \\
\hline Smbrmnjng Wetan (SP19) & 89,84 & 78,08 & 13,73 & 59,59 & 30,16 & 25,34 & 105,71 \\
\hline Bantur (SP20) & 97 & 85,23 & 19,91 & 66,74 & 37,18 & 32,37 & 112,95 \\
\hline Pakisaji (SP26) & 33,23 & 22,84 & 1,21 & 8,74 & 0,78 & $-0,05$ & 46,16 \\
\hline Tumpang (SP28) & $-0,94$ & $-7,6$ & $-12,09$ & $-9,67$ & $-10,82$ & $-10,63$ & 18,5 \\
\hline Kedungkandang (SP29) & $-3,17$ & $-3,92$ & $-4,04$ & $-4,04$ & $-4,03$ & $-4,01$ & 8,6 \\
\hline
\end{tabular}

Tabel 4. Jarak Tambahan (Gudang Klojen) pada Masing-masing Seed Point (dalam km)

\begin{tabular}{lccccc}
\hline \multicolumn{1}{c}{ Tujuan } & Seed Point 1 & Seed Point 2 & Seed Point 3 & Seed Point 4 & Seed Point 5 \\
\hline Kepanjen (SP6) & 31,06 & 21,78 & 16,38 & $-5,88$ & 36,4 \\
Sumberpucung (SP7) & 65,47 & 56,17 & 50,42 & 21,24 & 72,42 \\
Donomulyo (SP8) & 105,76 & 40,54 & 90,73 & 60,62 & 114,61 \\
Pagak (SP9) & 72,53 & 63,24 & 57,47 & 27,99 & 79,64 \\
Singosari (SP10) & 3,8 & $-3,23$ & $-5,15$ & $-6,99$ & 8 \\
Gondanglegi (SP16) & 33,41 & 24,35 & 19,28 & -2 & 36,72 \\
Turen (SP17) & 36,8 & 27,47 & 21,91 & $-3,1$ & 42,78 \\
Wagir (SP21) & 12,36 & 3,69 & $-0,55$ & $-9,16$ & 16,38 \\
Sukun (SP22) & 2,7 & $-2,8$ & $-4,68$ & $-8,55$ & $-0,34$ \\
Blimbing (SP23) & $-1,99$ & $-3,77$ & $-4,08$ & $-4,54$ & $-5,2$ \\
Klojen (SP24) & $-1,01$ & $-4,25$ & $-5,22$ & $-7,4$ & $-6,24$ \\
Bululawang (SP25) & 4,75 & $-2,02$ & $-4,41$ & $-8,37$ & 5,34 \\
\hline
\end{tabular}

Rute 1: SP8

Rute 2: SP6, SP10, SP22, SP25

Rute 3: SP7, SP9, SP16, SP17, SP21

Rute 4: SP23, SP24

Dengan jarak tambahan sebesar $66,21 \mathrm{~km}$. Solusi ini bukanlah merupakan hasil akhir dari perencanaan rute, tetapi masih membutuhkan pengurutan dalam pengiriman produk untuk rutenya, sehingga dari pengalokasian tiap wilayah pengiriman pada sebuah rute ini akan dilakukan pengurutan pengiriman di setiap rute adalah dengan menentukan urutan distributor pada rute, untuk perencanaan urutan ini penulis menggunakan metode nearest neighbour.

Analisis perencanaan urutan distributor pada rute dengan metode Nearest Neighbour (Chopra, S. dan Meindl, P., 2001). Hasil pengalokasian distributor pada masing-masing rute belum menunjukkan urutan dalam pengiriman produk kepada distributor sehingga perencanaan urutan ini perlu dilakukan. Tujuan dari urutan distributor pada rute ini adalah untuk meminimalkan jarak perjalanan yang harus ditempuh setiap kendaraan pengantar.Dalamperencanaanurutaninidigunakan metode Nearest Neighbour di mana metode ini merupakan metode pengurutan distributor dengan menambahkan distributor terdekat dari titik terakhir yang di kunjungi oleh kendaraan, artinya dari Distribution Center kemudian perjalanan dilakukan menuju ke konsumen yang paling dekat dengan Distribution Center tersebut.

Adapun hasil dari pengolahan dalam perencanaan urutan rute kendaraan pada masingmasing rute, yaitu:

(DC: Pakis)

Rute 1: DC - SP13 - SP15 - SP19 - SP20 - SP14 $-\mathrm{DC}$ 
Rute 2: DC - SP29 - SP2 - DC

Rute 3: DC - SP27 - SP28 - SP11 - SP4 - SP1 $-\mathrm{DC}$

Rute 4: DC - SP5 - SP3 - SP26 - SP18 - SP12 $-\mathrm{DC}$

dengan panjang jarak yang ditempuh yaitu: rute $1=201 \mathrm{~km}$, rute $2=34 \mathrm{~km}$, rute $3=81 \mathrm{~km}$, dan rute $4=183 \mathrm{~km}$

(DC:Klojen)

Rute 1: DC - SP8 - DC

Rute 2: DC - SP22 - SP25 - SP6 - SP10 - DC

Rute 3: DC - SP21 - SP17 - SP16 - SP9 - SP7 $-\mathrm{DC}$

Rute 4: DC - SP24 - SP23 - DC

dengan panjang jarak yang ditempuh, yaitu: rute $1=112 \mathrm{~km}$, rute $2=76 \mathrm{~km}$, rute $3=133 \mathrm{~km}$, dan rute $4=14 \mathrm{~km}$

Berdasarkan kedua hasil pengurutan Distributor pada rute ini menunjukkan bahwa pengurutan Distributor dalam pengiriman produk perlu di lakukan untuk meminimasi jarak dan waktu tempuh pengiriman.

Analisis perbandingan hasil perhitungan metode sebelum dan sesudah menggunakan metode Generalized Assignment.

Analisis perbandingan rute dan jarak

Perbandingan rute sebelum dan sesudah menggunakan Metode Generalized Assignment

Rute Awal

Untuk DC PAKIS

Rute 1: DC - SP5 - SP1 - SP3 - DC

Rute 2: DC - SP2 -SP4 - DC

Rute 3: DC - SP11 - SP12 - SP13 - DC

Rute 4: DC - SP15 - SP14 - DC

Rute 5: DC - SP18 -SP19 - DC

Rute 6: DC - SP20 - SP26 - DC

Rute 7: DC - SP27 - SP28 - SP29 - DC

Dengan panjang jarak yang ditempuh yaitu: rute $1=72 \mathrm{~km}$, rute $2=44 \mathrm{~km}$, rute $3=92 \mathrm{~km}$, rute $4=153 \mathrm{~km}$, rute $5=104 \mathrm{~km}$, rute $6=119 \mathrm{~km}$, dan rute $7=31 \mathrm{~km}$

Untuk DC KLOJEN

Rute 1: DC - SP6 - SP7 - DC

Rute 2: DC - SP8 -SP9 - DC

Rute 3: DC - SP21 - SP22 - DC

Rute 4: DC - SP24 - SP23 - SP25 - DC

Rute 5: DC - SP16 -SP17 - DC

Rute 6: DC - SP10 - DC
Dengan panjang jarak yang ditempuh yaitu jarak rute $1=78 \mathrm{~km}$, rute $2=114 \mathrm{~km}$, rute $3=32 \mathrm{~km}$, rute $4=39 \mathrm{~km}$, rute $5=55 \mathrm{~km}$, dan rute $6=$ $30 \mathrm{~km}$

Rute sesudah menggunakan metode Generalized Assignment

DC: Pakis

Rute 1: DC - SP13 - SP15 - SP19 - SP20 - SP14 $-\mathrm{DC}$

Rute 2: DC - SP29 - SP2 - DC

Rute 3: DC - SP27 - SP28 - SP11 - SP4 - SP1 - DC

Rute 4: DC - SP5 - SP3 - SP26 - SP18 - SP12 $-\mathrm{DC}$

Dengan panjang jarak yang ditempuh yaitu: rute $1=201 \mathrm{~km}$, rute $2=34 \mathrm{~km}$, rute $3=81 \mathrm{~km}$, dan rute $4=183 \mathrm{~km}$

DC:Klojen

Rute 1: DC - SP8 - DC

Rute 2: DC - SP22 - SP25 - SP6 - SP10 - DC

Rute 3: DC - SP21 - SP17 - SP16 - SP9 - SP7 - DC

Rute 4: DC - SP24 - SP23 - DC

Dengan panjang jarak yang ditempuh yaitu: rute $1=112 \mathrm{~km}$, rute $2=76 \mathrm{~km}$, rute $3=133 \mathrm{~km}$, dan rute $4=14 \mathrm{~km}$.

Berdasarkan hasil pengolahan data diperoleh perbedaan urutan rute dan total jarak pengiriman untuk masing-masing rute. Berdasarkan hasil pengolahan data dengan metode Generalized Assignment diperoleh rute untuk pengiriman barang yang dapat dilakukan perusahaan untuk 1 periode. Untuk lebih jelasnya, perbedaan antara metode baru dengan perusahaan dapat dilihat seperti Tabel 5.

Untuk rute dari Gudang Pakis. Berdasarkan Tabel 5 dapat dilhat adanya perbedaan antara hasil yang diperoleh berdasarkan perhitungan total jarak rute perusahaan dengan total jarak menggunakan metode Generalized Assignment. Pada Tabel 5, dapat dilihat pula penghematan jarak yang diperoleh dengan menggunakan metode Generalized Assignment. Pada periode 9, 10, dan 11 terjadi penghematan jarak sebesar $116 \mathrm{~km}$ dengan persentase $18,86 \%$.

Untuk rute dari Gudang Klojen. Berdasarkan Tabel 6 dapat dilihat adanya perbedaan antara hasil yang diperoleh berdasarkan perhitungan total jarak rute perusahaan dengan total jarak 
menggunakan metode Generalized Assignment. Pada Tabel 6, dapat dilihat pula penghematan jarak yang diperoleh dengan menggunakan metode Generalized Assignment. Pada periode 9, 10 dan 11 terjadi penghematan jarak sebesar $13 \mathrm{~km}$ dengan persentase $3,74 \%$.

Analisis perbandingan waktu pengiriman. Berdasarkan hasil pengolahan data diperoleh perbedaan urutan waktu pengiriman. Berdasarkan hasil pengolahan data dengan metode Generalized Assigment diperoleh perbedaan waktu pengiriman. Untuk lebih jelasnya, perbedaan antara metode baru dengan perusahaan dapat dilihat seperti Tabel 7.

Untuk rute dari Gudang Pakis. Pada Tabel 7 dapat dilhat adanya perbedaan antara hasil yang diperoleh berdasarkan perhitungan total waktu perusahaan dengan total waktu menggunakan metode Generalized Assignment. Pada Tabel 7, dapat dilihat pula penghematan waktu yang diperolehdengan menggunakan metodeGeneralized Assignment. Pada periode 9, 10, dan 11 terjadi penghematan waktu sebesar 1,92 jam dengan persentase $13,91 \%$.
Untuk rute dari Gudang Klojen. Pada Tabel 8 dapat dilihat adanya perbedaan antara hasil yang diperoleh berdasarkan perhitungan total waktu perusahaan dengan total waktu menggunakan metode Generalized Assignment. Pada Tabel 8, dapat dilihat pula penghematan waktu yang diperolehdenganmenggunakanmetodeGeneralized Assignment. Pada periode 9, 10, dan 11 terjadi penghematan waktu sebesar 0,21 jam dengan persentase $2,47 \%$.

Berdasarkan kedua perbandingan tersebut di atas, dapat dilihat bahwa metode Generalized Assignment dapat memberikan solusi alternatif yang lebih optimal untuk pengiriman produk di PT Indomarco Adi Prima dengan melihat penghematan waktu yang terjadi antara aktual perusahaan dengan metode Generalized Assignment. Sehingga metode Generalized Assignment ini dapat diterapkan oleh perusahaan.

Analisis perbandingan perhitungan biaya aktual perusahaan dan metode Generalized Assignment. Berdasarkan hasil pengolahan data diperoleh perhitungan biaya untuk metode Generalized Assignment dan aktual perusahaan seperti pada Tabel 9.

Tabel 5. Perbandingan Total Jarak Metode Generalized Assignment dan Aktual di PT Indomarco Adi Prima

\begin{tabular}{|c|c|c|c|c|}
\hline \multirow{2}{*}{$\begin{array}{c}\text { Periode } \\
\text { (dalam bulan) }\end{array}$} & \multicolumn{2}{|c|}{$\begin{array}{c}\text { Perbandingan Total Jarak Pengiriman } \\
\text { (dalam km) }\end{array}$} & \multirow{2}{*}{$\begin{array}{c}\text { Selisih } \\
\text { (dalam km) }\end{array}$} & \multirow{2}{*}{$\begin{array}{c}\begin{array}{c}\text { Persentase } \\
\text { penghematan } \\
(\%)\end{array} \\
\end{array}$} \\
\hline & Aktual Perusahaan & General Assignment & & \\
\hline 9 & 615 & 499 & 116 & 18,86 \\
\hline 10 & 615 & 499 & 116 & 18,86 \\
\hline 11 & 615 & 499 & 116 & 18,86 \\
\hline
\end{tabular}

Tabel 6. Perbandingan Total Jarak Metode Generalized Assignment dan Aktual di PT Indomarco Adi Prima

\begin{tabular}{ccccc}
\hline \multirow{2}{*}{$\begin{array}{c}\text { Periode } \\
\text { (dalam bulan) }\end{array}$} & \multicolumn{2}{c}{$\begin{array}{c}\text { Perbandingan Total Jarak Pengiriman } \\
\text { (dalam km) }\end{array}$} & \multirow{2}{c}{$\begin{array}{c}\text { Selisih } \\
\text { (dalam km) }\end{array}$} & $\begin{array}{c}\text { Persentase } \\
\text { penghematan } \\
(\%)\end{array}$ \\
\cline { 2 - 3 } & Aktual Perusahaan & General Assignment & & 3,74 \\
10 & 348 & 335 & 13 & 3,74 \\
11 & 348 & 335 & 13 & 3,74 \\
\hline
\end{tabular}

Tabel 7. Perbandingan Total Waktu Metode Generalized Assignment dan Aktual di PT Indomarco Adi Prima

\begin{tabular}{|c|c|c|c|c|}
\hline \multirow{2}{*}{$\begin{array}{c}\text { Periode } \\
\text { (dalam bulan) }\end{array}$} & \multicolumn{2}{|c|}{$\begin{array}{c}\text { Perbandingan Total Waktu Pengiriman } \\
\text { (dalam jam) }\end{array}$} & \multirow{2}{*}{$\begin{array}{c}\text { Selisih } \\
\text { (dalam jam) }\end{array}$} & \multirow{2}{*}{$\begin{array}{c}\text { Persentase } \\
\text { penghematan } \\
(\%)\end{array}$} \\
\hline & Aktual perusahaan & General Assignment & & \\
\hline 9 & 13,8 & 11,88 & 1,92 & 13,91 \\
\hline 10 & 13,8 & 11,88 & 1,92 & 13,91 \\
\hline 11 & 13,8 & 11,88 & 1,92 & 13,91 \\
\hline
\end{tabular}


Tabel 8. Perbandingan Total Waktu Metode Generalized Assignment dan Aktual di PT Indomarco Adi Prima

\begin{tabular}{cccccc}
\hline \multirow{2}{*}{$\begin{array}{c}\text { Periode } \\
\text { (dalam bulan) }\end{array}$} & \multicolumn{2}{c}{$\begin{array}{c}\text { Perbandingan Total Waktu Pengiriman } \\
\text { (dalam jam) }\end{array}$} & \multirow{2}{c}{$\begin{array}{c}\text { Selisih } \\
\text { (dalam jam) }\end{array}$} & \multicolumn{2}{c}{$\begin{array}{c}\text { Persentase } \\
\text { penghematan } \\
(\%)\end{array}$} \\
\cline { 2 - 3 } & Aktual perusahaan & General Assignment & & 2,47 \\
10 & 8,5 & 8,29 & 0,21 & 2,47 \\
11 & 8,5 & 8,29 & 0,21 & 2,47 \\
\hline
\end{tabular}

Tabel 9. Perbandingan Biaya Aktual Perusahaan dan Metode Generalized Assignment

\begin{tabular}{cccccc}
\hline \multirow{2}{*}{$\begin{array}{c}\text { Periode } \\
\text { (dalam bulan) }\end{array}$} & \multicolumn{2}{c}{$\begin{array}{c}\text { Perbandingan Total Biaya Pengiriman } \\
\text { (dalam Rp) }\end{array}$} & \multicolumn{2}{c}{$\begin{array}{c}\text { Selisih } \\
\text { (dalam Rp) }\end{array}$} & \multicolumn{2}{c}{$\begin{array}{c}\text { Persentase } \\
\text { penghematan } \\
\text { (\%) }\end{array}$} \\
\cline { 2 - 3 } & Aktual perusahaan & General Assignment & & 31,70 \\
10 & 6.430 .600 & 4.392 .069 & 2.038 .531 & 31,70 \\
11 & 6.430 .600 & 4.392 .069 & 2.038 .531 & 31,70 \\
\hline
\end{tabular}

Tabel 10. Perbandingan Biaya Aktual Perusahaan dan Metode Generalized Assignment

\begin{tabular}{cccccc}
\hline \multirow{2}{*}{$\begin{array}{c}\text { Periode } \\
\text { (dalam bulan) }\end{array}$} & \multicolumn{2}{c}{$\begin{array}{c}\text { Perbandingan Total Biaya Pengiriman } \\
\text { (dalam Rp) }\end{array}$} & \multicolumn{2}{c}{$\begin{array}{c}\text { Selisih } \\
\text { (dalam Rp) }\end{array}$} & $\begin{array}{c}\text { Prosentase } \\
\text { penghematan } \\
(\%)\end{array}$ \\
\cline { 2 - 3 } & Aktual perusahaan & General Assignment & & 22,19 \\
10 & 5.478 .800 & 4.263 .211 & 1.215 .589 & 2,19 \\
11 & 5.478 .800 & 4.263 .211 & 1.215 .589 & 2,19 \\
\hline
\end{tabular}

Untuk rute dari Gudang Pakis. Pada Tabel 9 diperoleh selisih penghematan dalam perhitungan biaya untuk periode 9, 10 dan 11 sebesar Rp2.038.531,00 yang berarti dalam 1 periode persentase penghematan sebesar $31,70 \%$.

Untuk rute dari Gudang Klojen. Pada Tabel 10 diperoleh selisih penghematan dalam perhitungan biaya untuk periode 9, 10 dan 11 sebesar Rp1.215.589,00 yang berarti dalam 1 periode persentase penghematan sebesar $22,19 \%$. Dengan demikian, dari kedua tabel hasil perhitungan biaya antara kedua metode di atas dapat dikatakan metode Generalized Assignment layak untuk diterapkan.

\section{SIMPULAN}

Berdasarkan hasil analisis yang dilakukan, maka dapat ditarik simpulan sebagai berikut. Penghematan waktu yang diperoleh dengan menggunakan metode Generalized Assignment pada Gudang Pakis. Pada periode 9, 10 dan 11 terjadi penghematan waktu sebesar 1,92 jam dengan persentase $13,91 \%$. Sedangkan pada Gudang Klojen terjadi penghematan waktu sebesar 0,21 jam dengan persentase 2,47\%. Berdasarkan perhitungan total jarak rute perusahaan dengan total jarak menggunakan metode Generalized Assignment. Dapat disimpulkan bahwa penghematan pada Gudang Pakis, pada periode 9, 10 dan 11 terjadi penghematan jarak sebesar $116 \mathrm{~km}$ dengan persentase 18,86\%.Sedangkan pada Gudang Klojen 11 terjadi penghematan jarak sebesar $13 \mathrm{~km}$ dengan persentase $3,74 \%$. Berdasarkan perhitungan biaya transportasi sebelum dan sesudah menggunakan metode Generalized Assignment maka diperoleh selisih penghematan dalam perhitungan biaya untuk periode 9, 10 dan 11 sebesar Rp2.038.531,- yang berarti dalam 1 periode persentase penghematan sebesar $31,70 \%$. Sedangkan pada Gudang Klojen diperoleh selisih penghematan dalam perhitungan biaya sebesar Rp1.215.589,00 yang berarti dalam 1 periode persentase penghematan sebesar $22,19 \%$.

\section{DAFTAR PUSTAKA}

Ballou, H.R., 2004. International Edition Logistics/Supply Chain Management. Fifth Edition. Prentice-Hall International, Inc.

Baroto, T., 2002. Perencanaan dan Pengendalian Produksi. Jakarta: Ghalia. 
Chopra, S. dan Meindl, P., 2001. Supply Chain Management: Strategy Planning and Operation. First Edition. Pearson Prentice-Hall International, Inc.

Herjanto, E., 1999 Manajemen Produksi dan Operasi, Edisi kedua, Grasindo.

Hugos, M., 2004. Essensials of Supply Chain Management, First Edition. Publisher Wiley.

Makridakis, S., Wheelwright, S.C., Mc. Gee Victor E., 1998. Metode dan Aplikasi Peramalan:Edisi kedua. Jakarta: Erlangga.
Nasution, A,H., 2003. Perencanaan dan Pengendalian Produksi. Jakarta. Edisi Pertama. Guna Widya.

Salim, A.H.A., 1998. Manajemen Transportasi. Edisi ke-empat. Jakarta: PT Raja Grafindo Persada.

Yamit, Z., 2003. Manajemen Persediaan. Edisi Pertama. Ekonisia, Kampus Fakultas Ekonomi UII Yogyakarta. 